\title{
LAICIDADE E LIBERDADE RELIGIOSA NO BRASIL: SITUANDO A DISCUSSÃO ENTRE RELIGIÃO E POLÍTICA
}

\author{
SECULARISM AND RELIGIOUS FREEDOM IN BRAZIL: SITUATING THE DISCUSSION \\ BETWEEN RELIGION AND POLITICS
}

MaIlson Fernandes CABRAL De SOUZA ${ }^{(*)}$

\begin{abstract}
RESUMO
A laicidade é um conceito central para o debate sobre o lugar que a religião deve ocupar no espaço público, do papel do Estado na garantia da liberdade religiosa e da isonomia das diferentes religiões perante a lei. O presente artigo tem o objetivo de analisar essa questão no âmbito brasileiro. Para isso, em um primeiro momento, será apresentado o percurso histórico da noção de tolerância religiosa até a emergência do conceito de laicidade. Em seguida, será desenvolvido um itinerário teórico da laicidade e suas tipologias. Por último, serão expostos seus desdobramentos no campo político brasileiro no que tange à liberdade religiosa, em especial, a aprovação pelo Plenário do Conselho Nacional do Ministério Público da proposta de recomendação que visa assegurar nos órgãos do poder público, a observância do princípio constitucional da laicidade.
\end{abstract}

Palavras-Chave: Laicidade. Liberdade religiosa. Tolerância religiosa.

\begin{abstract}
Laicity is a central concept for the debate about the place that religion should occupy in the public space, the role of the State in guaranteeing religious freedom and the equality of different religions before the law. This paper aims to analyze this issue in the Brazilian context. For this purpose, in a first moment will be presented the historical route of the notion of religious tolerance until the emergence of the concept of laicity. Then, a theoretical itinerary of secularity and its typologies will be developed. Finally, it will be exposed its developments in the Brazilian political field regarding religious freedom, especially the probation by the Plenary of the National Council of the Public Prosecution of the proposal of recommendation that aims to ensure in the organs of public power the observance of the constitutional principle of laicity.
\end{abstract}

KEYWORDS: Laicity. Religious freedom. Religious tolerance.

\section{INTRODUÇÃO}

\section{DA TOLERÂNCIA À LAICIDADE}

Pode-se dizer que, na relação entre religião e política, o problema da liberdade religiosa é uma questão fundamental para uma sociedade livre, posto que se trata da possibilidade de, como cidadão, ter-se o direito à liberdade de crença e de pensamento sem ser coagido por isso. Nesse sentido, a afirmação

\footnotetext{
* Mestre em Ciências da Religião pela Universidade Católica de Pernambuco, UNICAP. Graduado em Gestão de Turismo pelo Instituto Federal de Educação, Ciência e Tecnologia de Pernambuco, IFPE. O presente artigo é um desdobramento do estudo realizado na dissertação de mestrado do pesquisador. Email: mailsoncabral@yahoo.com.br.
} 
histórica da tolerância religiosa na modernidade europeia ocidental caracterizase não só como uma defesa da liberdade religiosa, mas também da emancipação do ser humano, tal como aponta Cardoso (2003):

A tolerância é uma questão ética central na história moderna. Em seu sentido primeiro, refere-se à liberdade religiosa plantada pela Reforma, porém a tolerância religiosa faz parte de um processo histórico mais amplo: o desenvolvimento gradual da liberdade humana (CARDOSO, 2003, p. 22).

Dessa forma, a noção de tolerância surge inicialmente como um valor de cunho religioso que passou a ser assimilado por toda a sociedade liberal burguesa. A partir do século XVII, surgem as formulações mais significativas em torno do conceito: a ideia de separação entre igreja e Estado ganha força, e a de liberdade do indivíduo de escolher suas próprias crenças, também¹ . (GOULART, 2012).

Construído sob a égide da tendência intelectual do Iluminismo - que pretende combater a superstição e o poder a partir da razão (ROUANET, 1987) -, o conceito de tolerância surgiu como resposta a situações de conflito por diferenças de pertença religiosa e de liberdade de consciência. No pensamento iluminista, destaca-se a ênfase em valores como a igualdade, a liberdade e a fraternidade ${ }^{2}$. Foi por meio dele que a tolerância religiosa ganhou solidez como ideário político. Tal postura encontra seu marco histórico na Declaração dos Direitos do Homem e do Cidadão, em 26 de agosto de 1789, onde é expressa a defesa desses valores:

$\mathrm{X}$ - Ninguém pode ser incomodado por causa das suas opiniões, mesmo religiosas, contanto que não perturbem a ordem pública estabelecida na lei.

XI - A livre comunicação de pensamentos e opinião é um dos direitos fundamentais do homem; todo cidadão pode, pois falar, escrever, imprimir livremente, sob a condição de responder pelo abuso dessa liberdade nos casos determinados pela lei (UNESCO apud CARDOSO, 2006, p. 177).

\footnotetext{
${ }^{1} \mathrm{Na}$ modernidade, são os maiores expoentes em defesa da tolerância: Baruch Espinosa (Tratado teológicopolítico, séc. XVII); John Locke (Carta sobre a tolerância, séc. XVII); Pierre Bayle (Comentário filosófico sobre estas palavras de Jesus Cristo "obriga-os a entrar", séc. XVII); Voltaire (Tratado sobre a tolerância, séc. XVIII); Marquês de Condorcet (Cinco memórias sobre a instrução pública, séc. XVIII); Stuart Mill (Sobre a liberdade, séc. XIX). Em suas obras, esses pensadores fundamentam a discussão sobre o tema no contexto do pensamento liberal (CARDOSO, 2003; LACERDA, 2014).

2 Convém apresentar a divisão feita por Rouanet (1987), em que o autor diferencia o Iluminismo como uma propensão intelectual não limitada a uma época específica, e a Ilustração como uma corrente de ideias que floresceu no século XVIII: "Pertencem ao Iluminismo as correntes de ideias que combatem o mito e o poder, utilizando argumentos racionais. A definição é grosseira, mas basta para nossos fins. O movimento intelectual que floresceu no século XVIII pode ser denominado de Ilustração. Ela foi uma importantíssima realização histórica do Iluminismo - talvez a mais importante, mas não a primeira, e certamente não a última” (ROUANET, 1987, p. 301-302).
} 
Nesse contexto, a tolerância ganhou a legitimidade de status político para as sociedades contemporâneas, tornando-se ponto fulcral para as discussões em torno dos direitos de primeira geração, isto é, os princípios básicos da igualdade e legalidade na sociedade (REIMER, 2013). Assim, a liberdade religiosa se afigurou como um desses princípios, tendo sido positivada na segunda metade do século XVIII em conjunto com as declarações norte-americanas (Declaração de Direitos da Virgínia, em 1776, e United States Bill of Rights, em 1789) e francesa (Declaração dos Direitos do Homem e do Cidadão, em 1789).

Apesar disso, o conceito de tolerância comporta em si limites e contradições na medida em que: "A mesma razão que levantou a bandeira da tolerância religiosa na modernidade nutre raízes profundas de certas formas de intolerância que tanta violência e dor provocaram no mundo contemporâneo" (CARDOSO, 2003, p. 81). Em outras palavras, o mesmo ideal iluminista que promoveu esse conceito legitimou tacitamente as formas atuais de intolerância cultural, étnica, racial e religiosa, mantendo também implícito o cristianismo como seu horizonte cultural.

Nessa perspectiva, a própria constituição linguística e histórica do termo nas línguas latinas foi semanticamente marcada por uma relação de subordinação e dominação cultural, caracterizando-se o senso comum sobre a tolerância como um valor pejorativo:

Os sentidos de tolerância, predominantes nos dicionários das línguas latinas, revelam a ideologia da cultura europeia em seu projeto de universalidade e homogeneidade pela dominação das outras culturas. No século XVI, o vocábulo latino tollerantia significa constância em suportar, permitir, condescender. Nessa acepção, a tolerância supõe uma relação humana entre desiguais, em que o superior faz concessões ao inferior. Assim, o verbo "tolerar" aparece frequentemente como sinônimo de "suportar" ou "aceitar com indulgência". Nesses dois sentidos básicos estão presentes (sic) a postura discriminatória e superior dos conquistadores e colonizadores europeus em relação aos povos indígenas na América Latina (ZEA, 1995, p. 92 apud CARDOSO, 2003, p. 132, grifos do autor).

Ao longo do século XX, buscaram-se outras óticas de compreensão sobre a tolerância que levassem em conta a diversidade cultural e as desigualdades sociais dos povos não europeus. Nesse sentido, a Organização das Nações Unidas para a Educação (UNESCO) lançou, em 1995, a Declaração de Princípios sobre a Tolerância, na qual se encontra o termo sob essa nova ótica:

A tolerância não é concessão, condescendência, indulgência. A tolerância é, antes de tudo, uma atitude ativa fundada no reconhecimento dos direitos universais da pessoa humana e das liberdades fundamentais do outro. Em nenhum caso a tolerância poderia ser invocada para justificar lesões a esses valores 
fundamentais. A tolerância deve ser praticada pelos indivíduos, pelos grupos e pelo Estado. (UNESCO apud CARDOSO, 2003, p. 192).

Dessa forma, é possível compreender que a noção de tolerância possui diferentes nuances, contudo, ela foi tema fundamental para os pensadores da modernidade e também orientou a formação da política hodierna. Com a institucionalização social e política da tolerância religiosa, tornou-se possível a emergência e o desenvolvimento do conceito e prática da laicidade do Estado, o que permitiu cessar o vínculo entre crença religiosa e pertencimento político no contexto das repúblicas modernas (LACERDA, 2014).

\section{LAICIDADE: ORIGENS, SIGNIFICADOS, CONCEITOS, CONEXOS E TIPOLOGIAS}

A laicidade se apresenta como um problema político, no que tange ao posicionamento do Estado em face de questões que envolvam a liberdade religiosa. Partindo-se da perspectiva da Teoria Política Normativa 3 , como propõe Lacerda (2014), a laicidade pode ser compreendida a partir da formalização de tipos e de padrões de sua institucionalização. Sob essa dimensão teórica, o conceito consiste em que:

[...] o Estado não professa nem favorece (nem pode professar ou favorecer) nenhuma religião; dessa forma, ele contrapõe-se ao Estado confessional - em que se inclui o assim chamado "Estado ateu", considerando que este assume uma posição caracteristicamente religiosa, mesmo que seja em um sentido negativo. Dessa forma, seguindo a laicidade, o Estado não possui doutrina oficial, tendo como consequências adicionais que os cidadãos não precisam filiar-se a igrejas ou associações para terem o status de cidadãos e inexiste o crime de heresia (ou seja, de doutrinas e/ou interpretações discordantes e/ou contrárias à doutrina e à interpretação oficial). (LACERDA, 2014, p. 181).

Ou seja, a filiação religiosa não se constitui como prerrogativa para o direito à cidadania, e o poder público é imobilizado pela abstenção de assumir uma religião oficial ou dogma civil. Há, assim, uma dissociação entre lei civil e normas religiosas: passa-se a organizar a vida política do Estado sem a prerrogativa de um fundamento transcendente.

Essa separação entre o religioso e o não religioso em esferas diferentes também pode ser apreendida na própria origem etimológica do vocábulo4:

\footnotetext{
3 Essa ramificação da Teoria Política pode ser classificada da seguinte forma: "Ela é comumente chamada de normativa, no sentido que se preocupa com aquilo que 'deve ser', com nossos valores e crenças, e com nossas escolhas individuais e coletivas. Isso não significa necessariamente que tal teoria não tenha base empírica. [...] muitas de suas formulações têm diagnósticos sofisticados e muito convincentes daquilo que ‘é', ou seja, do mundo atual, e esses diagnósticos são muito importantes na reflexão daquilo que 'deve ser"” (FERES JÚNIOR 2010, p. 65, grifos do autor).

4 Ranquetat Junior (2008) afirma que: "Segundo Blancarte (2000), o termo laicidade foi utilizado pela primeira vez em um voto que o conselho geral de Seine na França, fez em favor do ensino laico, não
} 
A expressão laicidade deriva do termo laico, leigo. Etimologicamente laico se origina do grego primitivo Laos, que significa povo ou gente do povo. De Laos deriva a palavra grega laikós de onde surgiu o termo latino laicus. Os termos laico, leigo exprimem uma oposição ao religioso, àquilo que é clerical (CATROGA, 2006 apud RANQUETAT JUNIOR, 2008, p. 62, grifos do autor).

Como preceito político, a laicidade se aplica ao Estado, sendo distinta, mas decorrente da secularização5. Huaco (2008) apresenta uma distinção didática entre os dois processos: "a laicidade é a expressão político-institucional do processo de secularização (das instituições estatais, de seu ordenamento, de suas políticas, etc.) que acaba moldando-se formalmente mediante normas, princípios e valores jurídicos.” (HUACO, 2008, p. 47). Para Casanova (2006), a secularização é um processo social mais amplo que corresponde à progressiva perda de influência dos valores religiosos no espaço público. Como processo histórico, ela pode ser entendida como uma tentativa de eliminar o dualismo estrutural da cristandade medieval que dividia o mundo entre o religioso e o secular.

A respeito da oposição secular versus religioso e da origem do termo secularização, Casanova (2011) defende que eles possuem um significado inicialmente teológico:

Qualquer discussão sobre o secular tem que começar com o reconhecimento de que ele primeiro emerge como uma categoria teológica da cristandade ocidental que não tem equivalente em outras tradições religiosas ou até no cristianismo oriental. Originalmente, a palavra latina saeculum, como em per saecula saeculorum, significava apenas um período indefinido de tempo. Mas eventualmente, tornou-se um dos termos da díade religioso/secular, que serviu para estruturar toda a realidade espacial e temporal da cristandade medieval em um sistema binário de classificação separando dois mundos, o mundo de salvação religioso-espiritual-sagrado e o mundo secular-temporal-profano. Consequentemente, a distinção entre o clero "religioso" ou regular, que se retirou do mundo para os monastérios para levar uma vida de perfeição cristã, e o clero "secular", que viveu no mundo junto com os leigos. (CASANOVA, 2011, p. 56, tradução nossa' ${ }^{6}$.

confessional e sem instrução religiosa. Este fato ocorreu no século XIX” (RANQUETAT JUNIOR, 2008, p. 64).

5 Para Santos (2014), o surgimento do processo histórico de secularização tem o seu momento fundador em 1648, com o Tratado de Westphalia, que pôs termino às guerras religiosas conhecidas por Guerra dos Trinta Anos. Já para Berger (1985), a questão da secularização é mais complexa, havendo os seus indícios no próprio judaísmo.

${ }^{6}$ Any discussion of the secular has to begin with the recognition that it emerged first as a theological category of Western Christendom that has no equivalent in other religious traditions or even in Eastern Christianity. Originally, the Latin word saeculum, as in per saecula saeculorum, only meant an indefinite period of time. But eventually, it became one of the terms of a dyad, religious/secular, that served to structure the entire spatial and temporal reality of medieval Christendom into a binary system of classification separating two worlds, the religious-spiritual-sacred world of salvation and the seculartemporal-profane world. Hence the distinction between the 'religious' or regular clergy, who withdrew 
No tocante ao conceito de secularização, Casanova (2006) estabelece que o termo deva ser distinguido em três diferentes conotações: a) como o declínio das crenças e práticas religiosas nas sociedades modernas, em favor de práticas e crenças não religiosas; b) como a privatização da religião, entendida como uma tendência geral histórico-moderna e de condições normativas, isto é, as manifestações públicas da religião deixaram de ser aceitas e passaram para o âmbito do foro íntimo; c) como a diferenciação das esferas seculares - Estado, economia, ciência - emancipadas das instituições e normas religiosas, operando por regras próprias. Em conformidade com esse entendimento, o processo de secularização criou as condições necessárias para a laicização do Estado7.

Sob esse viés, é possível inferir que a laicidade é um princípio que oscilará para a sua maior ou menor efetivação em cada contexto político a depender do grau de secularização de uma determinada sociedade.

Precedida e pressuposta pelo processo de secularização que gerou condições para o seu estabelecimento, a laicidade, ${ }^{8}$ para Lacerda (2014), deve apresentar três aspectos: a separação entre Estado e igreja; a inexistência de doutrina oficial de Estado, e o pressuposto social da secularização. Por meio dessa tripartição, é possível perceber que, historicamente, a concretização do Estado laico é recente, situando-se entre o final do século XVIII e o século XIX, e que a simples separação entre Igreja e Estado não se configura como garantia da laicidade. Essa distinção pode ser observada em outros contextos históricos: "[...] tal foi a situação característica da alta Idade Média, em que a famosa 'ida a Canossa' do imperador germânico Henrique IV, em 1077, indicou a submissão política do poder Temporal ao poder Espiritual do papa Gregório VII" (LACERDA, 2014, p. 182).

Sob esses aspectos, a laicidade se consolidou, em grande parte das sociedades contemporâneas no ocidente, não só como um conceito políticonormativo, mas também como um instrumento na garantia das liberdades e direitos civis. A esse respeito, Blancarte (2008) afirma que: “O Estado laico é a primeira organização política que garantiu as liberdades religiosas. Há que se

from the world into the monasteries to lead a life of Christian perfection, and the 'secular' clergy, who lived in the world along with the laity.

7 Como aponta Huaco (2008), são nos países de hegemonia católica que as discussões em torno da laicidade se tornaram mais intensas, enquanto em países de predominância protestante há um maior foco para a noção de secularização. A laicidade tomada como valor político é própria da emergência do contexto republicano francês e dos países inspirados nesse modelo. Mariano (2011) também afirma que os processos de laicização em diversos países da América Latina foram inspirados no ideário francês.

8 Uma vez que na presente pesquisa pretende-se definir a laicidade a partir de um quadro teórico normativo, não serão abordados os debates específicos da Sociologia da Religião que versam sobre a secularização. Para uma abordagem clássica da temática nesse campo, conferir Berger (1985) e, para uma panorâmica sobre o debate sociológico acerca do conceito de laicidade e sua comparação com o conceito de secularização, conferir Mariano (2011). 
lembrar que a liberdade de crenças, a liberdade de culto e a tolerância religiosa foram aceitas graças ao Estado laico, e não em oposição a ele.” (BLANCARTE, 2008, p. 29).

Apesar disso, é relevante trazer para a discussão uma crítica feita por Lacerda (2014) acerca do sentido negativo atribuído à laicidade: trata-se do laicismo, isto é, a pretensão de estender o processo de laicização do Estado e suas instituições políticas para o âmbito da sociedade. Para Lacerda (2014), essa terminologia constitui-se um equívoco conceitual e político, posto que:

[...] sendo a laicidade uma situação institucional, mas também um valor a respeitar-se, o laicismo seria o movimento ao seu favor. Assim, não nos parece aceitável a definição formulada por intelectuais e movimentos contrários, seja à laicidade, seja à secularização, que afirmam respeitar a laicidade, mas atribuem ao termo derivado "laicismo" o sentido negativo do que Kintzler chama de "integrismo laico"9 (LACERDA, 2014, p. 190).

O laicismo implica uma desvalorização implícita da noção de laicidade, comprometendo-a como valor social e político. Historicamente, a principal opositora ao conceito de laicidade tem sido a Igreja Católica, estabelecendo-lhe o sentido pejorativo e propondo expressões como laicidade sã e laicidade bem entendida, a fim de conservar, ainda que veladamente, a confessionalidade estatal (HUACO, 2008).

Os termos "laicismo", "Estado laico", e "separação Igreja-Estado" sempre serão concebidos de maneira muito negativa, ora forte, como na Igreja pré-conciliar, ora moderados, como na Igreja pós-conciliar. (HUACO, 2008, p. 53-54).

Por definição, a laicidade desloca da fé o status organizador da discussão política e a coloca como uma questão de foro íntimo, mas, paralelamente, torna o espaço público aberto para a discussão de temas do interesse de todos os cidadãos. Em outras palavras, o vínculo religioso deve estar separado de pertença política, tal como propõe Kintzler (2008):

A laicidade abre um espaço cívico e crítico comum. Ela demanda de cada um, primeiro na escola e depois como cidadão, de dar um passo além de sua origem, de fazer um esforço para não se reduzir a um pertencimento prévio, a que ninguém tem que renunciar. (KINTZLER, 2008 apud LACERDA, 2014, p. 188).

Dessa forma, a afirmação da laicidade é a marca constituinte para uma república livre, sendo compreendida como o regime não monárquico e das

9 Ultralaicismo e integrismo laico são as terminologias propostas por Kintzler para essa deriva da laicidade (LACERDA, 2014). 
liberdades civis em que o Estado é controlado pela sociedade para que ele não se torne dominador (LACERDA, 2014).

Nesse sentido, convém salientar o caráter especificamente republicano, em vez de democrático, da laicidade, tal como apresentado por Lacerda (2014):

Entendendo-se o republicanismo como a preocupação com instituições capazes de regular a vida política e social e a democracia como o imperativo da vontade da maioria, a laicidade aproxima-se mais do ideal da república do que do de democracia (LACERDA, 2014, p. 199).

A oposição república-democracia é heurística para a compreensão da laicidade, haja vista que é, a partir da garantia da liberdade de crença e convicção, que os atores sociais se organizam e reivindicam seus direitos no espaço público. Sob essa ótica, a república tem como centro de sua temática o cuidado pela coisa pública (res publica), o autogoverno e a autocontenção, enquanto a democracia se caracteriza como o regime do povo, em que o desejo de ter, a temática do poder e das relações sociais estão congregadas ${ }^{10}$ (RIBEIRO, 2000). Associada unicamente ao viés republicano a laicidade deixa de congregar as lutas sociais e os direitos humanos como parte de sua pauta política, ao passo que, articulada apenas à perspectiva democrática, pode ser fragilizada e relativizada em detrimento da vontade da maioria da população. Uma vez que essa vontade pertença a um determinado seguimento religioso hegemônico na sociedade, este pode fazer valer sua influência religiosa e política sobre o Estado e as leis.

Nesse sentido, a laicidade deve intercalar as duas noções, à medida que congregue em si a demanda por igualdade social, assim como a preservação das liberdades individuais nas relações entre religião e Estado. Em outras palavras, o conceito de laicidade, de origem republicana, complementa-se na democracia, ampliando o poder de participação dos cidadãos na esfera política.

Para uma tipificação da noção de laicidade, Lacerda (2014) propõe dois critérios analíticos: a) a existência ou não de um projeto previamente elaborado de laicidade que anteceda a sua institucionalização; b) que na formulação dos seus princípios informativos a laicidade esteja vinculada aos processos sociopolíticos específicos de cada país. O autor apresenta dois modelos de

\footnotetext{
${ }^{10}$ É salutar ressaltar que a divisão proposta pelo autor não encerra as discussões sobre o tema: "Sem dúvida alguma é possível argumentar que a teoria democrática não se resume à vontade da maioria, ou à 'vontade popular', da mesma forma que cada vez mais há inúmeras vertentes da teoria democrática que se preocupam com as salvaguardas a serem conferidas aos grupos minoritários; inversamente, é possível argumentar que há distintas vertentes do pensamento republicano, algumas mais próximas da "vontade popular' e outras mais próximas de arranjos institucionais que salvaguardam minorias.” (LACERDA, 2014, p. 199-200).
} 
laicidade: um de vertente francesa, a laicidade de princípio, e outro de vertente americana, a laicidade de compromisso ${ }^{11}$.

A primeira vertente adota como princípio de liberdade a recusa da confessionalidade estatal, posto que a relação entre os cidadãos e Estado deva se restringir à política, não lhe cabendo a imposição de sua opinião sobre os cidadãos. Na segunda vertente, o Estado laico é uma solução de compromisso diante da impossibilidade dos diferentes credos de se imporem social e politicamente. Nesse modelo, a laicidade não é apreendida como um condicionante da liberdade pública, porém como produto da incapacidade de uma religião se sobrepor em relação às demais (LACERDA, 2014).

Apesar das semelhanças entre modelos no que tange à posição do Estado em relação às denominações religiosas, a perspectiva inversa é distinta:

[...] enquanto na variedade de princípio a laicidade é uma situação por assim dizer indisputável, pois a laicidade é fundamento do Estado e garantia das liberdades públicas, na variedade de compromisso a laicidade é um valor transitório ou passível de ser percebido como tal enquanto perdura uma situação de ausência de hegemonia religiosa em uma sociedade dada. (LACERDA, 2014, p. 193).

Dito em outros termos: a partir do momento em que uma determinada religião se torna majoritária, a laicidade não sofre modificações na vertente de princípio, ao passo que, na vertente de compromisso, ela poderá perder força como preceito político, comprometendo a isonomia das religiões perante a lei.

\section{LAICIDADE E LIBERDADE RELIGIOSA NO BRASIL}

O modelo de laicidade do Brasil sofreu influências francesas e norteamericanas na sua formação, não havendo uma proposta elaborada prévia à sua institucionalização, mas um projeto tomado de empréstimo. Prevaleceu assim, no caso brasileiro, a laicidade de princípio (LACERDA, 2014; LEITE, 2011).

Nesse contexto, a separação entre religião e política se constituiu, ao menos formalmente, a partir do surgimento da República, em 1889, quando o regime do padroado é extinto e a Igreja Católica perde sua primazia como religião oficial do país ${ }^{12}$. A liberdade de culto é constitucionalmente estabelecida a todo e

\footnotetext{
${ }^{11}$ Como a discussão proposta sobre a laicidade desenvolvida nesta seção se filia à perspectiva teóriconormativa de Lacerda (2014), não serão abordadas outras tipologias de laicidades, como as desenvolvidas por Blancarte (2008) e Oro (2008).

${ }^{12}$ A discussão não adentrará em torno da liberdade religiosa no Brasil Império, à medida que o foco da presente pesquisa está sobre a laicidade e a matriz desse princípio é estabelecida no país com o advento do republicanismo. No que concerne às relações entre Estado e religião no período imperial, cumpre assinalar que: "Sob a aparência de uma Constituição que privilegiava uma confissão e apenas tolerava as demais,
} 
qualquer grupo religioso através do Decreto 119-A, de 17 de janeiro de 1890, instaurando a separação entre Igreja e Estado (SILVA, 2007). Na Constituição republicana de 1891 é estabelecida oficialmente a liberdade de culto, e reafirmado o postulado do Decreto 119-A.

Não obstante, sucedeu-se que na prática: “[...] o que se impôs na realidade foi um modelo de cooperação e proximidade entre Estado e religião, com o previsível destaque à religião majoritária.” (LEITE, 2011, p. 51). Nesse sentido, Leite (2011) pontua que não existia nesse período um consenso entre os principais juristas, como Rui Barbosa e João Barbalho, do que viesse a significar um Estado laico brasileiro:

[...] não havia, por parte da doutrina, uma compreensão homogênea e consensual a respeito das relações entre Estado e religião na Constituição de 1891, o que se revelará particularmente na interpretação de certas normas. E, se nem mesmo entre os juristas da época havia um consenso na identificação de um projeto laicista no texto constitucional de 1891, é problemático sustentar que tal consenso se fizesse na prática, no âmbito de uma sociedade que seguia majoritariamente católica (LEITE, 2011, p. 44-45).

Com efeito, embora a liberdade religiosa apareça esboçada na primeira Constituição republicana, o percurso histórico para o reconhecimento dos direitos e garantias fundamentais se deu a partir de mudanças dos valores dominantes em meio às transformações sociais e mudanças econômicas ${ }^{13}$ (REIMER, 2013). O catolicismo continuou a exercer grande influência na política nacional, especialmente durante as décadas de 1920 e 1930, na figura do Cardeal Dom Sebastião Leme da Silveira Cintra, defensor da interpretação do Brasil como Nação Católica e do reestabelecimento da união Igreja-Estado. Em suma, o Cardeal Leme defendia a recatolização do país e o retorno aos privilégios da Igreja, todavia sem impedimentos tributários impostos à ela, como no período imperial (DELLA CAVA, 1975). Essa visão estava atrelada ao movimento de romanização ${ }^{14}$ promovido pelo Vaticano, possuindo um profundo viés político-teológico:

havia um quadro um pouco mais complexo. A Constituição do Império era, guardadas as proporções, restritiva em relação às religiões em geral, tanto a católica quanto as acatólicas”. (LEITE, 2011, p. 34).

${ }^{13} \mathrm{~A}$ esse respeito, Leite (2011) faz uma importante observação: "[...] ao se evitar o estabelecimento de associações ideológicas primárias entre República, espaço público, democracia, laicidade e liberdade religiosa, deve-se compreender o advento do novo regime como um momento institucional singular para a reorganização das relações entre Estado e religião, mudança que interessava universalmente a todas as confissões, ainda que em graus distintos" (LEITE, 2011, p. 38).

14 O movimento é caracterizado da seguinte forma por Azzi (1992): "Na realidade, não é possível analisar a característica da catolicidade desvinculando-a da romanidade. Como a partir de meados do século XVIII, parte expressiva do clero francês aderira à ideologia liberal, veiculada pelos enciclopedistas, o grupo fiel à Santa Sé passou a ser designado como ultramontano, ou seja, aquele que se alinhava ao lado do Pontífice Romano, o qual residia, a partir da ótica francesa, além dos Alpes, ou seja, ultramontes”. (AZZI, 1992, p. 109). 
É fato que, onde quer que o Estado liberal republicano chegou [sic] ao poder, a Santa Sé procurou tirar proveito das liberdades constitucionais e incentivou as hierarquias nacionais a darem o máximo de si para promover os objetivos da Igreja. Mas Roma preferia, antes de tudo, uma Igreja unida oficialmente ao Estado ou, então, pelo menos uma concordata entre a Santa Sé e um Estado secular, não obstante a ideologia deste. (DELLA CAVA, 1975, p. 12).

A respeito desse período, Azzi (2008) acrescenta que o episcopado e os pensadores católicos se opuseram com veemência à orientação laica do Estado, objetando-se principalmente contra: a) a introdução do ensino leigo nas escolas; b) a laicização dos cemitérios; c) o decreto de separação entre Igreja e Estado. A influência hegemônica católica se fez presente no texto constitucional de 1934, uma vez que as seguintes concessões foram estabelecidas no documento: a) o casamento religioso passava a ter validade civil e o divórcio foi proibido; b) foi facultado nas escolas públicas o ensino religioso durante o período de aulas; c) ao Estado foi permitido o financiamento de escolas, hospitais, escolas e quaisquer atividades da Igreja Católica sob a forma de interesse coletivo (DELLA CAVA, 1975).

Todavia, com o estabelecimento do Estado Novo (que perdurou de 1937 a 1945) e a promulgação da Constituição de 1937, esses privilégios são suprimidos da Carta Magna, embora eles tenham permanecido na prática, haja vista que a aliança política entre a Igreja e o governo permaneceu. Della Cava (1975) argumenta que as concessões à Igreja foram mantidas, posto que, sob uma perspectiva sociológica, o catolicismo consistia num sistema religioso que fornecia legitimidade social para o governo. Mesmo com o fim da Era Vargas e promulgação da Constituição de 1947, questões como a indissolubilidade e a manutenção do ensino religioso confessional15 nas escolas públicas permaneceram no texto constitucional.

Com o advento do golpe militar, em 1964, a Carta Magna foi temporariamente suspensa. O governo outorgava "por si mesmo o poder constituinte" (REIMER, 2013, p. 69), governando por meio de decretos-leis, isto é, os Atos Institucionais (AI). A nova Constituição elaborada sob o regime militar entrou em vigor em 1967. No que tange à questão religiosa, ela manteve a semelhança com a anterior.

$15 \mathrm{O}$ ensino religioso no Brasil esteve, desde o início, diretamente associado ao modelo colonial português. A educação religiosa era uma questão de cumprimento de acordos entre a instituição Católica e a coroa portuguesa, ficando a educação a cargo dos jesuítas (JUNQUEIRA, 2011). Mesmo com o surgimento da república, o ensino religioso continuou a ser ofertado nas escolas públicas de forma facultativa. Somente na formulação da lei de diretrizes e bases para a educação, sancionada em 20 de Dezembro de 1996, o ensino religioso aparece com as seguintes características: sem ônus para os cofres públicos, facultativo, confessional ou interconfessional (ALVES; JUNQUEIRA, 2011). Instituições como o FONAPER (Fórum Nacional Permanente do Ensino Religioso), tem se engajado na defesa de um ensino religioso não confessional e sua inclusão na nova lei de diretrizes e bases para a educação. 
Nesse sentido, só a partir do processo de redemocratização no Brasil e da promulgação da Constituição de 1988, também conhecida como constituição cidadã, a semântica da liberdade religiosa passa a situar-se dentro da lógica de um Estado democrático de direito. No artigo $5^{\circ}$, incisos VI a VIII, do texto constitucional estão as referências explícitas sobre a liberdade religiosa:

VI - é inviolável a liberdade de consciência e de crença, sendo assegurado o livre exercício dos cultos religiosos e garantida, na forma da lei, a proteção aos locais de cultos e suas liturgias;

VII - é assegurada, nos termos da lei, a prestação de assistência religiosa nas entidades civis e militares de internação coletiva;

VIII - ninguém será privado de direitos por motivo de crença religiosa ou de convicção filosófica ou política, salvo se as invocar para eximir-se de obrigação legal a todos imposta e recusar-se a cumprir a prestação alternativa, fixada na lei (BRASIL, 1988).

Nesses incisos, estão condensados os elementos fundamentais relativos à questão religiosa, podendo ser a liberdade religiosa subdividida em pelo menos quatro aspectos, como propõe Reimer (2013): a) liberdade de consciência: liberdade matricial, isto é, dela derivam todas as liberdades, e remete ao âmbito do direito subjetivo e da autonomia moral-prática; b) liberdade de crença: liberdade de uma consciência livre determinar-se a ter uma crença religiosa ou não, sendo essa decisão de foro íntimo; c) liberdade de culto: trata-se da garantia de exteriorização comunicativa de crença ou fé individual; e d) liberdade de organização: refere-se à dimensão coletiva da liberdade de culto para reunião ou associação com fins religiosos ${ }^{16}$.

Ao longo do texto constitucional também existem outras referências relativas ao tema, como o artigo 19, inciso I, que veda aos entes estatais associar-se a organismos religiosos, exceto na colaboração de interesses coletivos; e o artigo 150, inciso VI, que trata da isenção tributária sobre os templos de qualquer culto.

Em síntese, são sob essas características que a Constituição vigente baseia a construção do Estado laico brasileiro. Ela foi explicitamente marcada pela laicidade de princípio, rejeitando a confessionalidade estatal e assegurando a isonomia entre os diferentes credos e formas de organização religiosa. Porém, como apresentado na seção anterior, a violação à liberdade religiosa e as denúncias de casos de intolerância religiosa têm aumentado no país, exigindo um posicionamento mais efetivo do Estado frente a esse problema.

${ }^{16}$ A assistência religiosa para as pessoas que se encontram em locais de internação coletiva em entidades civis ou militares se enquadra entre as categorias de liberdade de crença e de culto (REIMER, 2013). 
Pelo que precede, é possível afirmar que é sob esse cenário que se delineia a questão da liberdade religiosa no Brasil. A partir das garantias de liberdade de crença e de convicção asseguradas pela Constituição, os atores sociais se organizam a fim de reivindicar seus direitos no espaço público. Nesse sentido, são as políticas públicas em defesa da laicidade que visam a assegurar o cumprimento dos direitos constitucionais referentes à questão religiosa.

\section{UM CAMINHO PARA A EFETIVAÇÃO DA LAICIDADE}

$\mathrm{Na}$ atualidade, o principal ponto de avanço na consolidação da laicidade foi a aprovação, em fevereiro de 2017, pelo Plenário do Conselho Nacional do Ministério Público (CNMP), da proposta de recomendação que visa assegurar a observância do princípio constitucional da laicidade nas funções executiva, legislativa e judiciária no Estado brasileiro:

O Plenário do Conselho Nacional do Ministério Público (CNMP) aprovou a proposta de recomendação que visa a garantir a fiel observância e a concretização do princípio constitucional do estado laico no exercício das funções executiva, legislativa e judiciária do Estado brasileiro, inclusive com a adoção de políticas públicas que reforcem a neutralidade estatal em sua atuação frente às questões religiosas. A aprovação aconteceu nesta terça-feira, 21 de fevereiro, durante a $4^{\mathrm{a}}$ Sessão Ordinária de 2017. (CNMP, 2017).

Por meio dessa proposta, recomenda-se aos ramos do Ministério Público e às unidades dos Ministérios Públicos dos Estados a empenharem esforços para a elaboração e a implementação de políticas públicas e medidas administrativas pautadas no princípio da laicidade frente às orientações religiosas (CNMP, 2017). Dentre as diretrizes a serem adotas por esses órgãos, está a de fomentar medidas representativas da aplicação da laicidade, e a conscientização de seus agentes e servidores.

Com essa ação do CNMP, é possível observar o funcionamento do que Lacerda (2014) conceituou como laicidade de princípio, isto é, a não confessionalidade estatal, sendo a laicidade uma condicionante da liberdade religiosa e fundamento das liberdades públicas, independentemente da existência de uma hegemonia religiosa na sociedade.

Nesse sentido, o CNMP endossa a compreensão da laicidade como o ato do Estado não poder professar nem favorecer nenhuma religião, o que, consequentemente, não obriga os cidadãos a estarem vinculados a um segmento religioso ou associações para manterem o status de cidadão (LACERDA, 2014).

Embora seja uma ação embrionária no âmbito do poder público, ela oferece indícios de que um novo quadro para a defesa da liberdade religiosa se 
consolida no contexto brasileiro. Em função disso, é necessário acompanhar os futuros desdobramentos dessa proposta de recomendação.

Em abril de 2017, uma primeira repercussão da recomendação aconteceu na cidade do Recife, Pernambuco. Seguindo a orientação do CNMP, o Ministério Público de Pernambuco (MPPE) publicou uma recomendação solicitando que não seja autorizada a prática de liturgias ou rituais religiosos na Câmara dos Vereadores de Recife:

Manifestações religiosas, citações e invocações ao nome de Deus são corriqueiras na Câmara dos Vereadores de Recife. E em cima do princípio de laicidade, o Ministério Público de Pernambuco (MPPE) publicou uma recomendação no Diário Oficial dessa quinta-feira (20) para que a Mesa Diretora da Casa José Mariano não autorize ou permita a realização de encontros em que haja prática de liturgias ou rituais religiosos no interior da Casa Legislativa. O promotor de justiça Eduardo Luiz Cajueiro, autor da recomendação, estabeleceu o prazo de 20 dias para que o presidente da Câmara, Eduardo Marques (PSB), informe à procuradoria as providências que estão sendo tomadas para cumprir a decisão. Caso a recomendação seja descumprida, o MPPE pode adotar medidas judiciais para corrigir as irregularidades e os agentes públicos poderão ser responsabilizados (JCONLINE, 2017).

Diante disso, observa-se que a defesa da laicidade passa a ganhar maior aderência por parte do judiciário a partir da recomendação do CNMP, uma vez que ela funciona como uma diretriz para as demais instâncias do poder público sobre o tema.

Nesse sentido, cabe apontar ao menos dois possíveis desdobramentos para a ação do CNMP. O primeiro seria o da construção de parâmetros básicos para orientar o exercício da laicidade do Estado, fornecendo definições básicas para a garantia do seu funcionamento. $O$ segundo seria a possibilidade de se caracterizar quais situações se configuram casos de violência e intolerância religiosa e como essas ações devem ser penalizadas, uma vez que violam o direito à liberdade religiosa.

Por meio disso, seria possível trazer não só maior clareza para cada agente e servidor público, no exercício de sua função, da necessária distinção entre convicções e crenças religiosas da sua posição enquanto funcionário público, como também oferecer, para a sociedade civil, um maior entendimento do espaço cívico e crítico comum que se abre para os cidadãos por intermédio da laicidade.

CONSIDERAÇÕES FINAIS 
Em função do que foi apresentado, é possível percebe que, no Brasil, a influência da Igreja Católica junto ao poder público se mostrou notória ao longo da história, influenciando as relações entre religião e Estado. Essa influência, tal como argumentou Reimer (2013), estendeu-se também na forma como a liberdade religiosa era compreendida antes do processo de redemocratização do Brasil e do texto constitucional de 1988. Assim, a Constituição vigente é explicitamente marcada pela laicidade de princípio, vertente que rejeita a confessionalidade do Estado e assegura a isonomia entre os diferentes credos e formas de organização religiosa (LACERDA, 2014).

Em síntese, é possível dizer que a liberdade religiosa é garantida, no âmbito estatal, pelo princípio da laicidade. Como princípio presente na Carta Magna, ela assegura: o direito à liberdade religiosa; que a filiação religiosa não se constitui como prerrogativa para o direito à cidadania, e que o poder público é imobilizado pela abstenção de assumir uma religião ou dogma como oficial.

Pelo que precede, compreende-se que a questão da laicidade se torna relevante no cenário político brasileiro, tendo como uma de suas decorrências as recomendações do CNMP e do MPPE. Em ambos os casos, ela é evocada como um princípio inalienável, uma vez que a laicidade se torna um elemento central para a garantia da liberdade religiosa, como também funciona enquanto um demarcador da relação entre religião e política no espaço público no que tange ao estabelecimento de parâmetros básicos para o cumprimento desse princípio.

Nesse sentido, é por intermédio das políticas públicas que o cumprimento dos direitos constitucionais referentes à liberdade religiosa é garantido, tornando possível a efetivação da laicidade. Sendo assim, trazer à baila a discussão sobre as trajetórias da laicidade e da liberdade religiosa no caso brasileiro se torna crucial para a compreensão dos diferentes discursos que versam sobre o lugar que a questão da religião deve ocupar no espaço público na contemporaneidade como, por exemplo, os discursos que, numa orientação distinta da tomada pelo CNMP, reivindicam a religião como elemento constitutivo da vida pública, pondo em questão o seu confinamento à esfera particular ${ }^{17}$. Longe de esgotar a discussão, o propósito aqui almejado foi o de fornecer elementos para o aprofundamento desse debate.

\section{REFERÊNCIAS}

ALVES, Luiz Alberto de Souza; JUNQUEIRA, Sergio. A elaboração das concepções de ensino religioso no Brasil. In: JUNQUEIRA, Sergio; WAGNER, Raul. (Org.). O ensino religioso no Brasil. Curitiba: Champagnat, 2011, p. 55-84.

17 Para uma análise de discursos nessa perspectiva, conferir Souza e Aragão (2017). 
ARAGÃO, Gilbraz. Religiões e espaço público. In: ROSSI, Luiz Alexandre; JUNQUEIRA, Sérgio. (Org.). Religião, direitos humanos e laicidade. São Paulo: Fonte Editorial, 2015, p. 71-83.

AZZI, Riolando. Organização institucional católica. In: HOORNAERT, E. et al. (Org.). História da Igreja no Brasil: ensaio de interpretação a partir do povo. Terceira época (1930-1964). Petrópolis: Vozes, 2008, p. 423-442.

Paulinas, 1992.

O altar unido ao trono: um projeto conservador. São Paulo: Edições

BERGER, Peter. O dossel sagrado: elementos para uma sociologia da religião. São Paulo: Paulus, 1985.

BLANCARTE, Roberto. O porquê de um Estado laico. In: LOREA, Roberto Arriada. (Org.). Em defesa das liberdades laicas. Porto Alegre: Livraria do Advogado, 2008, p. 19-32.

BRASIL. Constituição da República Federativa do Brasil: 1988. Brasília, DF: Senado Federal: Centro Gráfico, 1988.

BURITY, Joanildo A. Redes, parcerias e participação religiosa nas políticas sociais no Brasil. Recife: Fundação Joaquim Nabuco, Massangana, 2006.

CARDOSO, Clodoaldo Meneguello. Tolerância e seus limites: um olhar latinoamericano sobre diversidade e desigualdade. São Paulo: UNESP, 2003.

CASANOVA, José. Rethinking Secularization: a global comparative perspective. The Hedgehog Review, Charlottesville, v. 8, n. 1-2, p. 7-22, 2006. Disponível em: $<$ www.iasc-culture.org/THR/archives/AfterSecularization/8.12CCasanova.pdf $>$. Acesso em: 03 abr. 2016.

The Secular, Secularizations, Secularisms. In: CALHOUN, Craig; JUERGENSMEYER, Mark; VANANTWERPEN, Jonathan. (Org.). Rethinking Secularism. New York: Oxford University Press, 2011, p. 54-74.

Conselho Nacional do Ministério Público. Recomendação visa a garantir a laicidade das funções executiva, legislativa e judiciária no Estado brasileiro. 21 fev. 2017. Disponível em: <www.cnmp.mp.br/portal/todas-asnoticias/10100-recomendacao-visa-a-garantir-a-laicidade-das-funcoes-executivalegislativa-e-judiciaria-no-estado-brasileiro>. Acesso em: 09 mar. 2017.

DELLA CAVA. Ralph. Igreja e estado no Brasil do século XX: sete monografias recentes sobre o catolicismo brasileiro, 1916-64. Novos Estudos, São Paulo, n. 12, p. 5-52, abr./jun. 1975. Disponível em: <http://www.cebrap.org.br/v2/files/upload/biblioteca _virtual/igreja_e_estado_no_brasil.pdf >. Acesso em: 06 out. 2015.

FERES JÚNIOR, João. Teoria política contemporânea: uma introdução. Rio de Janeiro: Elsiver, 2010.

GOULART, Rodrigo. Tolerância religiosa: origens históricas e implicações educacionais. In: ENCONTRO NACIONAL DE PRÁTICAS DE ENSINO, 16, 2012, Campinas. Anais... Campinas: UNICAMP, 2012. p. 3687-3698. Disponível em: 
<www.infoteca.inf.br/endipe/smarty/templates/arquivos_template/upload_arquivos/ acervo/docs/3407c.pdf >. Acesso em: 20 mar. 2016.

HUACO, Marco. A laicidade como princípio constitucional do Estado de Direito. In: LOREA, Roberto Arriada. (Org.). Em defesa das liberdades laicas. Porto Alegre: Livraria do Advogado, 2008, p.33-80.

JCONLINE. MPPE quer proibir manifestações religiosas na Câmara do Recife. 21 abr. 2017. Disponível em: <jconline.ne10.uol.com.br/canal/politica/ pernambuco/noticia/ 2017/04/21/mppe-quer-proibir-manifestacoes-religiosas-nacamara-do-recife279598.php>. Acesso em: 30 maio 2017.

LACERDA, Gustavo Biscaia de. Sobre as relações entre Igreja e Estado: conceituando a laicidade. In: Conselho Nacional do Ministério Público. (Org.). Ministério Público Em defesa do Estado Laico. Brasília: Conselho Nacional do Ministério Público, 2014, v.1, p. 179-206.

LEITE, Fábio Carvalho. O Laicismo e outros exageros sobre a Primeira República no Brasil. Religião \& Sociedade, Rio de Janeiro, vol.31, n.1, p. 32-6o, jun. 2011. Disponível em: <www.scielo.br/pdf/rs/v31n1/ao3v31n1.pdf>. Acesso em: 13 mar. 2016.

ORO, Ari Pedro. A laicidade na América Latina: uma apreciação antropológica. In: LOREA, Roberto Arriada. (Org.). Em defesa das liberdades laicas. Porto Alegre: Livraria do Advogado, 2008, p. 81-116.

RANQUETAT JUNIOR, C. A. Laicidade, laicismo e secularização: definindo e esclarecendo conceitos. Revista Tempo da Ciência, Santa Maria, v. 15, n. 30, p. 5972, 2008. Disponível em: <http://www.scielo.br/scielo.php?script=sci_nlinks\&ref $=000143 \&$ pid $=$ So101-7330201300030001400019\&lng=pt $>$. Acesso em: 13 mar. 2016.

RIBEIRO, Claudio de Oliveira. Religião, democracia e direitos humanos: pertença pública inter-religiosa no fortalecimento da democracia e na defesa dos direitos humanos no Brasil. São Paulo: Editora Reflexão, 2016.

RIBEIRO. Renato Janine. Democracia versus república: a questão do desejo nas lutas sociais. In: BIGNOTTO, Newton. (Org.). Pensar a república. Belo Horizonte: UFMG, 2000, p. 13-25.

REIMER, Haroldo. Liberdade religiosa na história e nas Constituições do Brasil. São Leopoldo: Oikos, 2013.

ROUANET, Sergio Paulo. As razões do Iluminismo. São Paulo: Companhia das Letras, 1987.

SOUZA, Mailson Fernandes Cabral; ARAGÃO, Gilbraz de Souza. Se não cabe ao Estado definir um conceito de religião, o que é um crime de intolerância religiosa? Uma análise discursiva. In: SILVA, Dalexon Sérgio da; SILVA, Francisco Vieira da. (Org.). Pêcheux e Foucault: caminhos cruzados na Análise do Discurso. São Carlos: Pedro \& João Editores, 2017, p. 61-78. Disponível em: <https://drive.google.com/file/d/ oBoDneSsHmljZEQ5MX VTODltNXc/view>. Acesso em 18 maio 2017. 